\title{
CURRENCY UNIONS: SOME LESSONS FROM THE EURO-ZONE
}

\author{
CHARLES A.E. GOODHART ${ }^{1}$ \\ Financial Markets Group \\ London School of Economics
}

\author{
Work in Progress \\ Draft - 18 July, 2006
}

\section{THE BENEFITS OF THE EURO-AREA}

Both the advantages and disadvantages of a currency union have been rehearsed at length in the context of the adoption of the single (euro) currency in the euro-zone. Amongst the potential advantages are:-

(a) Reduction in transaction costs;

(b) Increases in both the scale, competitiveness and liquidity of markets;

(c) Less external disturbance to the larger, more closed economy, and hence even greater price stability;

(d) Enhanced tendencies towards political and fiscal unity, with more internal risk sharing.

The experience of the euro-zone since its inception in January 1999 has been mixed. As a frequent traveller to many countries within the eurozone, I can vouch for the reduction in transaction costs. The introduction of euro notes and coins at the start of 2002 was a technical triumph, though slightly marred by a public perception that it led to a blip in inflation, from the rounding-up of prices of some frequently purchased small-value items (e.g. in kiosks). Not all cross-border transactions costs, for example via bank payments, have, however, declined as much as had been expected or will eventually occur.

1 I am grateful to Jonathan $\mathrm{Ng}$ for research assistance and to Iain Begg for many helpful comments. The errors and prejudices remain my own. 
Again experience in the unification and cost reduction in markets has been mixed. Within financial markets, fixed interest markets, both the money market and the euro-bond market, have been effectively unified, and their scale and efficiency increased. Europe is in the throes of merger negotiations amongst many of the national stock-markets, but for the time being there has been little change in the efficiency, costs or (clearing and settlement) procedures of the various (national) stock markets. Although there are now clear signs of more cross-border mergers amongst large banks, retail financial markets in banking and insurance, have remained separated, without much evidence of significant efficiency gains and cost reductions.

With the compression of twelve national currencies into a single euro-zone, a much larger share of trade of the individual enterprises has become internal within the euro-area. The euro-zone has become almost as much a closed economy as the USA or Japan; in 2003 the comparable data for foreign trade as a percentage of GDP are Japan 13.2\%, USA $14.4 \%$ and the Euro Area $16.7 \%$. This has the benefit of reducing the scale of shocks from external disturbances to the individual enterprise, or country, and this has been a significant boon. By the same token, however, the relatively closed nature of the euro-zone means that it will be less responsive to such exchange rate changes as do occur, and these may then have to be larger to have much aggregate effect. Since its formation in 1999 the euro has certainly fluctuated considerably against the US\$, and done so without any clear relationship with fundamentals. But these fluctuations were not noticeably greater than that of the $\mathrm{Dm} / \$$ exchange rate in the previous ten years. Moreover, the effective nominal (or real) exchange rate of the euro has fluctuated much less, because of the high weights of sterling and the Nordic currencies, plus the E. European, Mid-East and North African countries, whose currencies are quite closely aligned with the euro, see Figures 1-4 and Table 1. Although the euro has not become as close a rival to the $\$$ for international financial purposes, (reserve holding, invoicing, etc.) as some had hoped, its record on this front has been relatively successful.

There is, however, no doubt that the driving force for the adoption of greater European economic and monetary union (EMU) has been political, with the over-riding aim of achieving rapprochement between France and Germany and maintaining peace in the European area, though over-taken in the latest decade by the concept of 'return to Europe' for countries east and south east of the Oder river, the previous boundary with communist 
Eastern Europe. Monetary union was perceived as an important step in this process, of achieving ever greater harmony and unification within Europe. Moreover, it was quite widely recognized that there could be difficulties in combining a federal, unified monetary system with national, decentralised fiscal systems; the centralized community budget is very small, just over $1 \%$ of EU GDP, (and still largely dedicated to agricultural subsides and economic development support for the lower income parts of the EU, previously the Mediterranean, but increasingly now the Eastern European, countries). It was hoped that such pressures could induce both politicians and voters to accept the necessity of moving quite rapidly towards greater coordination and then unification of both fiscal policies and political sovereignty.

In this area, the outcome has been disappointing. There has been no significant move towards either coordination or centralisation in the fiscal domain. Attempts to agree the Community budget remain as fraught as ever, and the determination of national Ministers of Finance to minimise their own net national contribution mean that there has been no increase in centralised funds. Despite the formation of an informal Euro-group, comprising the Finance Ministers of the countries participating fully in monetary union, (working alongside the more formal Council of Ministers on which all 25 Member States sit), there has been no evidence of enhanced harmonisation of national fiscal policies, even amongst the narrower group of euro area members. The framework, provided by the Stability and Growth Pact, to prevent national Finance Ministers each trying to free-ride on the overall financial stability provided by the European Central Bank by expanding their own fiscal deficits, has been weakened by the refusal of Ministers to apply penalties to large member countries infringing the pact. The SGP has been redesigned in a somewhat more flexible manner. Yet, despite some scepticism whether, even in this revised format, it can provide firm limits to fiscal deficit finance, the main deficit countries, e.g. Italy, Germany, Greece, are trying to rein back their deficits, (albeit slowly), to permitted levels, and no country is openly and brazenly flouting the $3 \%$ level. Moreover there has been no sign of any return to the much larger deficits of the 1980s and early 1990s. As will be considered further below, the SGP appears, on comparative grounds, to be having some, potentially considerable, impact.

Meanwhile, any political process towards any greater centralisation, or federalism, has stalled with the 'No' vote by France and the Netherlands 
in the referendums on the 'Constitution'. This has not, however, in any way reduced the enthusiasm of Accession countries, (now full members, but still mostly waiting to join the eurozone) and candidate countries, for applying to join the EU, and thence the euro-area. Indeed one problem for the EU is that, with unchanged procedures, the rise in the number of member countries will cause the decision-making procedures to become more cumbersome and clogged. This will be so at the Governing Council of the European System of Central Banks (ESCB), as elsewhere in the EU. For this reason, at least some elements of the (rather grandiosely and unfortunately termed) 'Constitution' will need to be re-introduced and adopted to prevent the internal mechanisms of the EU from gumming up, whereby little or nothing can get done.

So there are signs that enthusiasm amongst the general public of the founding members of the EU for further centralisation and federation within the euro has been waning; perhaps particularly in France, since France's prior central role in influencing the European Commission, and the EU more broadly, has been diluted by the arrival of the new Accession countries to the East. On the other hand, enthusiasm to join this European club amongst the rest of the Balkans and in Turkey appears to remain as strong as ever.

\section{DISADVANTAGES OF A CURRENCY UNION: WORSENING PROBLEMS IN THE EURO-ZONE?}

The main disadvantage of adopting a currency union is that it limits the ability of the constituent regions (countries) to adjust to an (asymmetric) shock by using domestic monetary policy and exchange rate adjustments to do so. Furthermore the termination of the ability of the domestic, local government to turn to the use of the printing press, ${ }^{2}$ in extremis, to pay off its domestically denominated debt, raises the probability of default (counter-party risk) just when the temptation to increase deficit financing increases. So a currency union would generally seem to require some kind of sanction upon the ability of member states to run ever-larger deficits, à

2 By the same token, the ability to generate seignorage revenue is removed. In the EU, seignorage revenues obtained by the issue of euro notes and coins are, however, redistributed to the member nation states according to a formula relating to relative GDP and population. Under normal circumstances at least, this is not a serious disadvantage, or problem, of currency union. 
la SGP. Unless member states had been previously so virtuous as to build up sufficient lee-way to utilise in downturns, (and member states in the EU had not been so virtuous), this means that such constraints on fiscal expansion during downturns implies that discretionary fiscal policy also cannot be used in a counter-cyclical fashion. Indeed, given the operation of the automatic fiscal stabilizers, the SGP will tend to push countries facing slow growth and rising unemployment into pro-cyclical fiscal cuts, (e.g. in Germany, Italy and Portugal). While there is much scepticism about countries' ability to manage discretionary fiscal policy successfully, even when free to do so, nevertheless these constraints mean that Ministers of Finance in most countries in the euro-zone cannot make use of any of the traditional levers of demand management, i.e. exchange rates, interest rates or fiscal adjustments.

So what happens in such a currency union if an (asymmetric) shock occurs? Of course one hope is that all such shocks will be symmetric, but this is unlikely to hold, at least not indefinitely. ${ }^{3}$ Absent demand management instruments, the adjustment has to fall primarily on labour markets. This is where the main problem has arisen in the euro-zone, though the effects have differed from country to country.

It is now widely agreed that Germany entered the single currency at too high an exchange rate. Unification had led both to large-scale fiscal expenditures and a construction boom in the Eastern Lander. To prevent this causing inflation, the Bundesbank had raised interest rates. Initially this led to the collapse and break-up of the narrow exchange rate mechanism (in 1992/93). Once the other EU countries had more room to adjust exchange rates, they mostly depreciated against the Dm. So even by 1999 German competitiveness was historically poor. Using the, credible, threat that enterprises would relocate to cheaper countries, particularly across the borders in E. Europe, enterprises in Germany managed to restrain nominal wage growth. Unemployment also remained high. Aided by continuing increases in productivity, unit labour costs were held down, and fell relative to most other countries in the EU, see Figures 5 and 6. By the same token its real exchange rate declined, i.e. became more competitive. Meanwhile the combination of low increases in real incomes and high unemployment was

3 One such recent asymmetric shock has been the economic emergence of China. This has benefited German exports (machinery and capital goods) and harmed Italian exports (consumer goods, textiles, shoes, etc.). 
keeping down domestic demand, especially consumption. Together with the increasingly competitive exchange rate, this has led to a burgeoning current account surplus, and even more so trade, growing from year to year.

Since the euro-zone as a whole is running a quite small surplus with the rest of the world, this implies that other euro-area countries are running equivalent current account deficits, see Figures 7 and 8. Running such large deficits is not necessarily to be deplored. Canada and USA ran current account deficits virtually continuously until 1914. When the current account deficit is the counterpart of FDI and portfolio investment pursuing higher returns on capital in the context of good investment opportunities, and expected higher future exports, the conjunctural mix may be optimal, though even here the recipient country may be required to adjust rapidly if there should be some sudden stop to the capital flow, perhaps due to political or economic developments either at the sending or recipient country end. Moreover unit labour costs in the receipient country may be increasing faster than in the sending country, consistently with continuing equilibrium, if labour productivity in the tradable goods sector is growing significantly faster in the former (Balassa-Samuelson effect).

One can argue that this is happening, more or less, in the Eastern Accession states, though these are only now just beginning to join the euro-zone (i.e. Slovenia). Current account deficits are matched by capital inflows; investment and growth are much higher than in the euro-zone. Productivity increases are greater, so that, despite some rise in relative unit labour costs (RULC), only in a few countries (notably Hungary) are there signs of seriously worsening competitiveness, see Table 2. Even so, the current account deficit is matched in some of these countries by a large fiscal deficit, e.g. in Hungary, which indicates greater fragility. For a survey of such problems, see Menegatti and Roubini (2006).

The same beneficial circumstances do not, however, hold for the euro-zone countries with the largest proportionate current account deficits, (Greece, Portugal, Spain, Table 3). Spain is the country whose development perhaps most nearly matches the good story. Here there has been an investment boom, but this has been in housing and construction (public sector infrastructure), see Figures 9 and 10 rather than in business. Unemployment has been falling rapidly, albeit from the highest levels in the EU. However, wage growth has been quite rapid, and relative unit labour costs and real effective exchange rates have risen, making Spain comparatively 
uncompetitive, vis a vis Germany in particular, Table 4. Some sizeable part of the housing boom has been for second homes and tourist accommodation from the sun-starved residents of Northern Europe. This boom has been supported, and facilitated, by the sharp decline in real interest rates, first accompanying Spain's entry into the euro-zone and then continued by the world-wide expansion of liquidity in 2001/2004. The current recovery in interest rates, and some over-building, is likely to bring the housing boom (and associated capital inflow) to an end, leaving Spain somewhat exposed as a high cost, uncompetitive country. How it will then seek to adjust, and whether it will succeed, are yet to be seen, but at least this remains a question for the future.

The most immediate question relates to Italy, and perhaps to a slightly lesser extent to Greece and Portugal; the economic condition of these latter two countries is arguably worse than that of Italy, but they are much smaller in size, so their problems seem less crucial to the continuing conduct of the euro-zone. In these countries the current account deficits cannot be ascribed to a private sector investment surge, and an accompanying boom in domestic demand. Instead it is due to worsening competitiveness, and falling exports as a share of GDP, see Figure 11. Rather than a boom in domestic demand, this is quite weak, and supported by a fiscal deficit that is already broaching the SGP 3\% limit. Far from being able to support domestic demand by fiscal expansion, the new Italian government and its Minister of Finance, my friend Tommaso Padoa-Schioppa is having to introduce an interim budget to try to get nearer to the SGP limit. Indeed the fiscal positions in Greece, Italy and Portugal continue to deteriorate, albeit slowly, see Table 5 .

The decline in relative competitiveness, especially vis a vis Germany, is due to much higher growth in nominal wages, especially in Greece, and also, in Italy, to a slower growth in productivity, see Figures 12-14 and Table 6 . In past years this would have been corrected by a devaluation. Now both that, and higher domestic interest rates, are ruled out by membership of the EU. How will the worsening competitiveness be resolved? There could be some favourable mix of increasing Italian productivity, or rising German ULC, but it would be optimistic to bet on it.

The unhappy conclusion would seem to be that Italy (and Portugal and Greece) would seem to need a protracted series of years in which labour costs, and domestic demand, are held down (relatively to Northern Europe). 
There is some room for shifting taxes away from labour (reducing the tax wedge), but the constraint on wage demand will presumably come mainly from higher unemployment. The question inevitably arises whether this is politically feasible. We shall address this in Section 4. But first we shall use this background story to set out some lessons from the euro-zone for any group of countries seeking to establish a currency union.

\section{LESSONS FROM THE EURO-ZONE}

The first, and most important, lesson is that events, (economic, natural disasters, political, etc.) are bound to make the unit labour costs of some constituent members of a currency union uncompetitive from time to time. If exchange rate adjustment is to be ruled out, the desideratum is to have a labour market flexible enough to adjust without too large a cost in unemployment, and a social and political system disciplined enough to accept and absorb such extra unemployment as does occur. Germany (and the Netherlands) have met that test; one is less confident about Italy and Greece.

Labour market flexibility has two main facets, wage adjustment and geographical mobility. There is evidence in the USA that much of the adjustment there takes place via physical movements of workers (Blanchard and Katz, 1992). Real wage flexibility in the USA is not much greater than in the EU, but labour mobility is much higher, not only between EU countries, (where there are also regulatory obstacles), but also within countries, (e.g. between south and north Italy). Similarly the many stresses and strains of the Gold Standard were alleviated by the migration (during the bad times) of millions of people from Europe to the New World, notably to Argentina and the other temperate countries of South America, (Brinley Thomas, 1954). Can we now really expect, or would we welcome, a further exodus of families from the main Mediterranean countries, and where would they go? Given the declining birth rates in such countries, would an exodus of young families make the demographic structure (with a rising dependency ratio) fiscally intolerable? Can we, therefore, rule out the prospect of a resurgence in labour mobility resolving the problem of comparative unit labour costs?

If so, adjustment would have to come from protracted slow growth in wages in these countries, with consequential slow growth, or even declines, in real living standards. But there must remain questions whether 
this is (politically) feasible, especially if this should come to be perceived as the (self-imposed) consequence of the adoption of a monetary standard and convention, the single euro-currency.

There is a more optimistic scenario, connected with Bob Mundell. This is that capital mobility may take the place of labour mobility in a single currency area. There is no question that a single currency enhances capital mobility. The hope is that a rise in labour availability (i.e. unemployment) and constrained wages may make capital flow into such, previously uncompetitive, regions and thereby restore their productivity and growth. This prospect seems (to me) unconvincing as the deflationary pressure is likely to raise political and exchange rate risks, while the unemployed are quite likely to be less skilled and demotivated.

So, the first lesson from the euro-zone is do not attempt to form a currency union unless there are sufficiently flexible labour markets, allowing adjustment to adverse developments in competitiveness either by labour mobility or wage restraint. Can the euro-zone itself meet this test; perhaps?

But is this the sole criterion? Surely there have been some relatively successful currency areas where labour market flexibility was not so marked. How about the large countries, Australia, Brazil, Canada for example, where sheer size causes relocation difficulties? Even within Europe, East Germany became extraordinarily uncompetitive after re-unification, Southern Italy is (probably) uncompetitive vis a vis Northern Italy, and the north of the UK uncompetitive vis a vis the south.

In these cases another factor comes into play, which is fiscal and political unification. In most unitary states some $40 \%$, or so, of GDP passes through the fiscal centre in the form of tax revenues and expenditures. The equivalent sum in the EU is just over $1 \%$. The normal form of many taxes, e.g. on incomes and profits, and of some expenditures, e.g. on unemployment benefits, causes them to act as stabilisers, giving more time to regions hit with asymmetric adverse shocks to adjust. Although much of the adjustment could be regional, rather than cross-border, there are limits to this, particularly given the constraints of the SGP.

Meanwhile political and social cohesion will lead to some degree of continuing redistribution towards the poorer, less competitive, regions. 
This will not only provide some regions with support, but also the political and social cohesion will make such regions more willing to accept the pressures arising from being uncompetitive rather than wishing to break away to form their own separate currency area. So much so that the complaints in many European countries come from the more prosperous regions (North Italy, West Germany, Southern England) about their exorbitant tax burden, rather than from the receiving poorer regions, (Scotland being an exception, partly on the grounds that a separate Scotland could obtain all the North Sea oil revenues).

There was an attempt to shift some fiscal stabilisation functions to the EU centre, in which I participated, but it failed, (the story is told at greater length in Goodhart, 2006). As a result there are virtually no cross-border fiscal flows in the euro-zone for stabilisation or redistributive purposes. So, when a country as a whole comes under pressure to adjust its relative unit labour costs within the euro-zone, there are no stabilising fiscal flows from the EU centre to help smooth the transition; no redistributive fiscal flows to support the region in so far as it fails to make the transition; and not that much social and political cohesion to encourage it to bear the discipline and travails of the adjustment process.

So the second lesson from the euro-zone, is that the form of the underlying fiscal, social and political structure in the regions/ countries concerned is a key feature of the likely success of a currency union. If countries are essentially on their own, for political, social and fiscal purposes, a currency union will always be fragile. Seen in this light, the likelihood of a successful Asian currency union is minimal. There was a debate on this issue between the (predominantly German) 'economist' school and the (predominantly French) 'monetary' school. The 'economist' school argued that currency union should be the final, crowning capstone on a previous process of coordination and unification in other economic (e.g. fiscal), social and political fields. The 'monetary' school argued that monetary unification should be prior to, and would lead on to, coordination and unification in these other fields. The 'economist' school lost the initial battle over the sequencing of strategic policy changes, but may yet win the ultimate intellectual war. 


\section{ADJUSTMENT TO DECLINING COMPETITIVENESS?}

A current account deficit can occur for many reasons, some good such as internal investment boom financed by FDI capital inflows, some bad such as a loss of competitiveness caused by rising relative unit labour costs. But in all cases such a deficit has to be financed. In countries with their own separate currencies, and on a fixed exchange rate, such financing can become problematical, if the deficit becomes seen as potentially unsustainable, because of the associated foreign exchange risk.

Within a single currency union, there is no such regional foreign exchange risk. It is not possible to speculate against the Italian or the Spanish euro anymore than one can prefer the New York to the Californian dollar. Moreover, amongst regions within a single currency union, financing of regional deficits is much easier, indeed generally so painless as to be unnoticed. In the absence of any exchange risk, there will be net sales of financial assets by entities in the deficit area to investors in the surplus areas. Absent exchange risk, and especially within a single currency area, the elasticity of substitution between financial assets of the same credit rating (default risk) is likely to be very high. So, a minute change in relative rates can encourage a massive shift of deficit region financial assets into the hands of surplus area investors.

Does this mean that uncompetitive areas within a currency union can run an ever increasing current account deficit at relatively little cost? The answer to this is no. The lack of competitiveness will show up in the private sector in the guise of reduced profits/ worsening losses. Their credit rating (default risk) will worsen, making financing more expensive and problematical. Assuming the maintenance of currency union, bankruptcies in the private sector would enforce higher unemployment, labour emigration and wage restraint.

The conjuncture is slightly more complicated if the deficit financing is concentrated in the public sector, since there remains the myth that a sovereign country carries no default risk. When a sovereign country commands its own printing press, it always has the opportunity of paying off nominal interest and principal by inflationary expansion of the note issue. But that is, in truth, as much expropriation of creditors' real value as straightforward default. If the political situation is such that the government cannot, or will not, restore sustainability by raising the primary fiscal 
surplus sufficiently, than a country with its own currency has to choose between default, or inflation. In either case, a previously pegged exchange rate will also prove to be untenable. Russia in 1998 was an example of a sovereign country that chose default on its own debt rather than inflation, perhaps quite largely because much of its domestic debt was held by foreigners (financial companies).

The financial condition of the countries with the twin deficits (fiscal and current account) within the euro-zone is not (yet) remotely akin to that of Russia in 1998, (or to Argentina in 2000/1). But competitiveness continues to decline on average, the current account is worsening, and the fiscal deficit remains towards the upper end of the SGP limits in the Club Med countries (Portugal, Spain, Italy and Greece), though the fiscal position in better in Spain. Particularly following the Prodi victory in the Italian general election, the Club Med countries are in the process of trying to hold their fiscal deficits down to, or bring them below, the SGP limit. Perhaps partly in consequence, there are virtually no indications of any increase in risk premia in the yields of the Club Med long-term government debt, see Figure 15.

Within a true currency union, the underlying risks are always largely political, rather than just economic. A currency union breaks because a region within it chooses to leave the parent currency and (re)-establish its own separate currencies. There are many examples, especially attendant on the break-up of empires, Austro-Hungary in 1918, and the USSR and Yugoslavia more recently. The question in the euro-zone is whether the, potentially long-drawn-out, pain of the adjustment process is perceived as greater than the pain of exit from the euro, and immediate devaluation to restore competitiveness.

A key issue in the assessment of the cost of exit is how existing debts, both public and private, would be treated. Such debts are, of course, currently almost all denominated in euros. If all such debts were to be honoured in full, after exit and devaluation, the debt levels denominated in the new currency would jump. Debtors would be hard hit, though those with tradeable export earnings in euros/dollars and other foreign currencies could offset greater debt service by greater export earnings. Domestic creditors would get a windfall. Domestic debtors, without access to foreign earnings, including the public sector, would have worsened debt ratios. This would raise default risk. Meanwhile the refusal to bear the continuing 
costs of market adjustment, and the devaluation, would raise the risks of sharply worsening inflation in the exiting country. So one would expect nominal interest rates facing new borrowers in the exiting country would rise sharply. A combination of increased debt ratios and raised interest rates could prove a lethal cocktail.

Although the decision would depend on the precise numbers and conjuncture, if such a case were ever to occur, there would be a good chance that any decision to exit the euro-zone would have to be accompanied by a (unilateral) re-denomination of existing euro-debt, possibly both interest and principal, or maybe just principal, both public and private, into the new national currency. This, of course, would be the equivalent of a partial default for creditors in other countries. Foreign creditors of private sector debtors could seek to have the debtors declared bankrupt, and to attach their assets abroad, if not paid in full. The government of the exiting country would presumably allow, but not compel, their private sector debtors to pay foreign creditors in the new domestic currency (i.e. not in euro), so each private sector debtor could decide what was best for them.

Similarly, based on an analysis of the precise numbers and the conjuncture, the public sector debtors could decide to switch payments (of interest and principal, or only of principal) onto a redenominated basis, in terms of domestic currency. This would, no doubt, lead to a legal challenge in the European Court. It would seem unlikely that a member government of the EU could unilaterally renege in large part on its Euro denominated debts without getting kicked out of the European Union. That would be a major political crisis.

Simply reciting the problems involved in exiting the euro, to wit either a domestic debt crisis, or a unilateral redenomination of debt and a political crisis with other EU partners, reveals the huge costs involved in exiting the euro. So any such exit would seem extremely unlikely, for the time being at least, as indeed evidenced by the lack of risk premia on long-term government debt. But it is not impossible, the more so the longer and the more painful was the adjustment process.

If an exit was ever to come, it would be driven by political events, and could occur remarkably quickly (easily within a week). The trigger would be the claim of an opposition party that it had a policy ready to 
counter the current stagnation and deflation in a country adjusting to longdrawn-out competitiveness failures, at a stroke. The moment that market participants thought both that:

(1) an opposition party might exit and devalue if it came to power,

(2) and that that party had a significant chance of gaining power,

Then there would be dramatic rush by outsiders to sell resident assets, (and even perhaps to borrow in that country). Besides a sudden jump in interest rates, local banks would be squeezed unmercifully, as depositors would flee to banks situated elsewhere within the euro-zone or outside. The pressures could be so intense that decisions could be forced on countries before they felt comfortable to take them.

If there was to be a crisis, it would almost certainly prove to be contagious. If markets started to react sharply to a non-negligible possibility of one member of the Club Med exiting the euro, it would rapidly, (within a day), spread to the other members. Indeed, the prior use of the term Club Med suggests that there have been certain common factors in their economies, notably their declining relative competitiveness, especially vis a vis Germany. This does, perhaps, admit the question whether there might have been advantages in having two separate Euro-areas, a Southern zone and a Northern zone, both of which would have a single currency, but which would have floated (relatively) freely against each other.

Perhaps with hindsight this might have been a better design, but our actual historical path constrains our future options. The procedure of exiting the euro would call down such a cataclysmic economic and political crisis, that by far the greater likelihood is that deficit, uncompetitive countries will bite the bullet of disciplined adjustment. But the resulting pain and trauma could bring about the emergence of a populist, nationalist, demagogic, (anti-EU), politician. Then the sparks could really fly.

\section{CONCLUSIONS}

Michael Mussa used to remark, when he was Chief Economist at the IMF, that one of the main regularities in the world was that each country had its own individual currency. This is not what one might expect from Optimal Currency Area theory, in particular given the diversity 
of countries by size, openness, specialization or diversity of production, type of market mechanism, etc., etc. The only respect in which OCA theory has any empirical success is that really tiny countries (below the size of Iceland) usually share a currency with a larger neighbour. Indeed, the current fashion is to argue that currency union will endogenously encourage changes in the economies of the constituent nations so that they become OCA compatible ex post, even if not so ex ante. There is, as yet, relatively little evidence, one way or the other, on this from the experience of the euro-zone.

One major reason why political, and social, unification is so important is that it provides conditions under which the adjustment mechanism, to being uncompetitive, is facilitated. Labour mobility is much greater within, than between, countries. Cross-regional fiscal transfers help to smooth the adjustment process. Social and national unity makes break-away policies almost unthinkable and hence provides the cement to keep the discipline of adjustment in place.

None of the above are, as yet, strongly anchored in the eurozone. Admittedly capital mobility is high throughout the EU, but whether capital mobility can take the place of labour mobility is doubtful. Whether social discipline and labour market adjustments will be sufficiently well developed to allow the increasingly uncompetitive countries in the Club Med to restore their competitive position without politically unacceptable strains remains to be seen. We must hope that this will be so; the next five years will probably prove the decisive testing ground.

In my view the German 'economist' thesis is correct. Currency unification should be one of the final steps in a much longer process of harmonisation, coordination and unification in fiscal, social and political policies. If such ultimate federalism is not an objective, do not engage in currency unification in the meantime. With further moves towards federalism now stymied in the EU, I would argue that the earlier adoption of the single currency represented incorrect sequencing.

The counter-argument was that, without a fixed single currency, the benefits of a single goods market in the EU could have been jeopardised, if the public in member states accused each other of competitive devaluations: and also that monetary unification would expedite political and fiscal harmonisation. Especially if member countries would adopt common 
inflation targets, I doubt whether accusations of competitive devaluations would stick. And we know that the dynamism towards greater federalism has temporarily stalled.

Successful currency union requires similar successes in political unification. It is difficult to have the first without the second as well. 


\section{BIBLIOGRAPHY}

Blanchard, O. and L.F. Katz, 1992. "Regional Evolutions", Brookings Papers on Economic Activity, $\mathrm{N}^{\mathrm{o}}$, pp. 1-75.

Goodhart, C.A.E., 2006. "Replacing the Stability and Growth Pact”, Presidential Address, International Atlantic Economic Conference, Berlin, March 18, forthcoming International Atlantic Economic Review.

Menegatti, C. and N. Roubini, 2006. "Vulnerability in Central and Southern Europe", www.rgemonitor.com.

Thomas, Brinley, 1954. Migration and Economic Growth, (Cambridge University Press). 


\section{Figure 1}

DM/\$ Exchange Rate

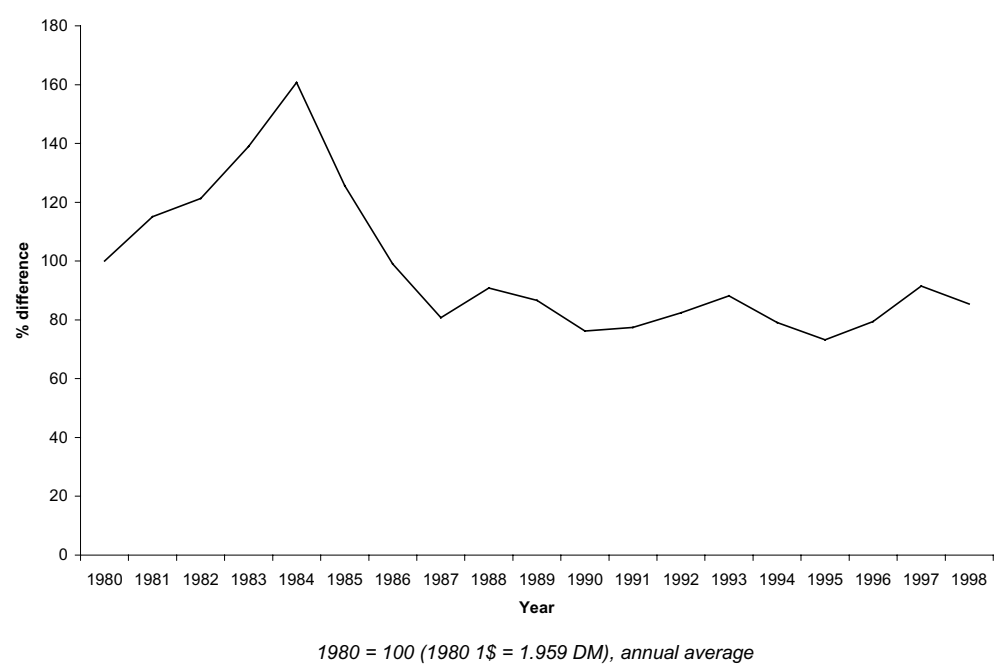

Source: International Financial Statistics May 2006

Figure 2

$€ / \$$ Exchange Rate

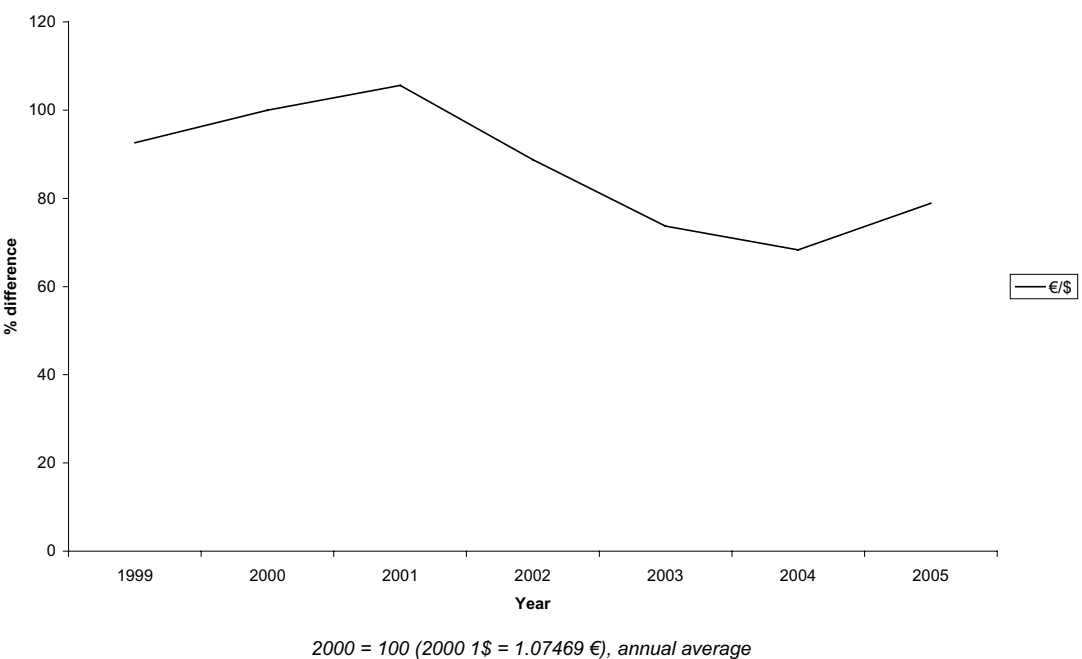

Source: International Financial Statistics May 2006 


\section{Figure 3}

Nominal Effective Exchange Rate; Index Numbers $(2000=100)$ : Period Averages

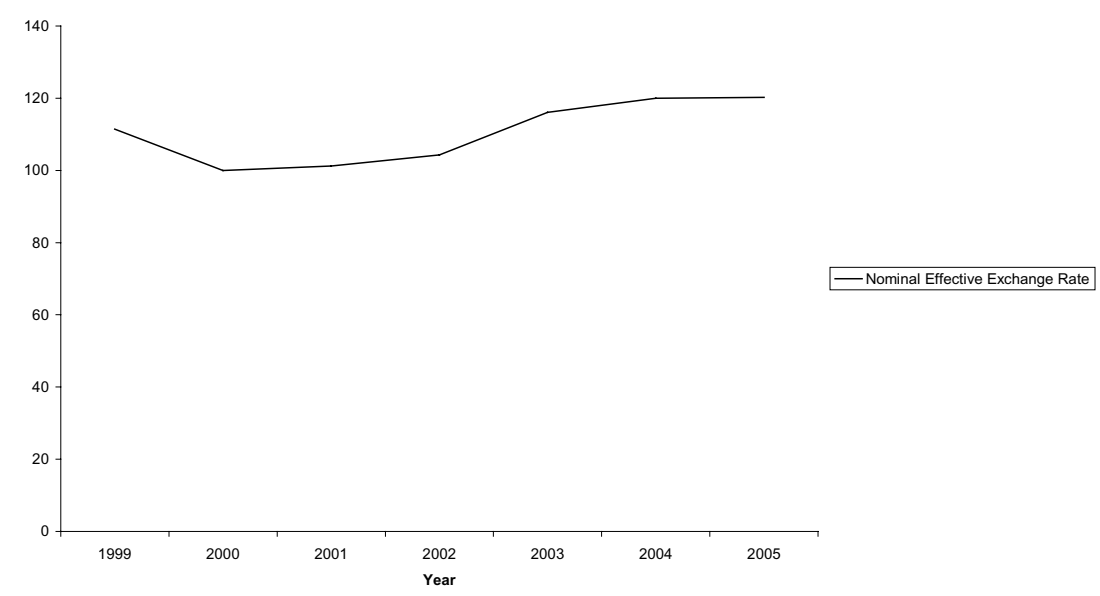

Source: International Financial Statistics May 2006

Figure 4

Real Effective Exchange Rate; Index Numbers $(2000=100)$ : Period Averages

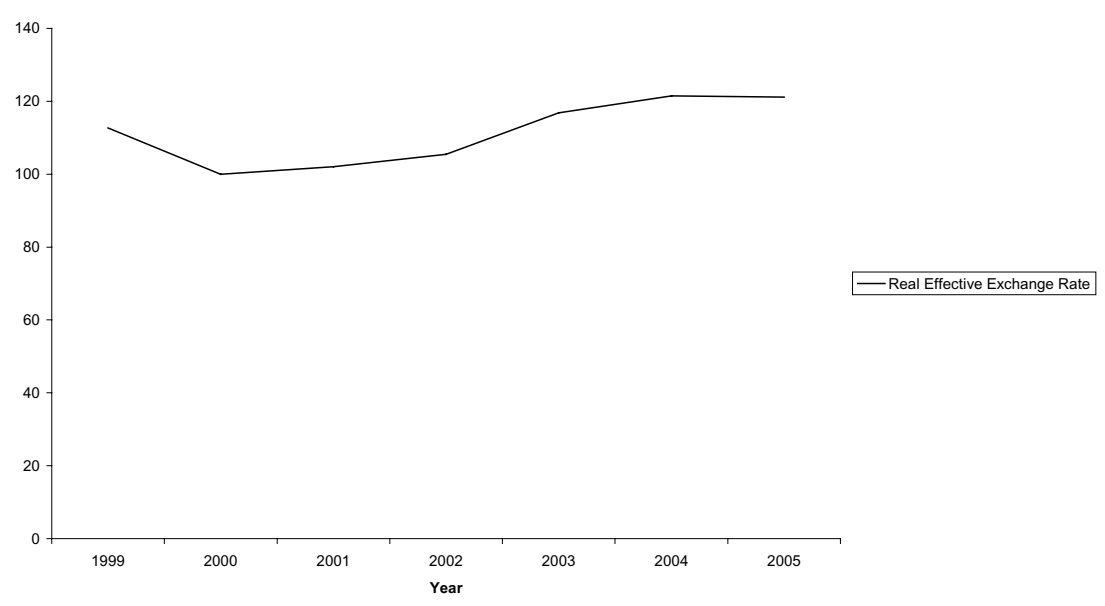

Source: International Financial Statistics May 2006 


\section{Figure 5}

Unit Labour Costs, Whole Economy

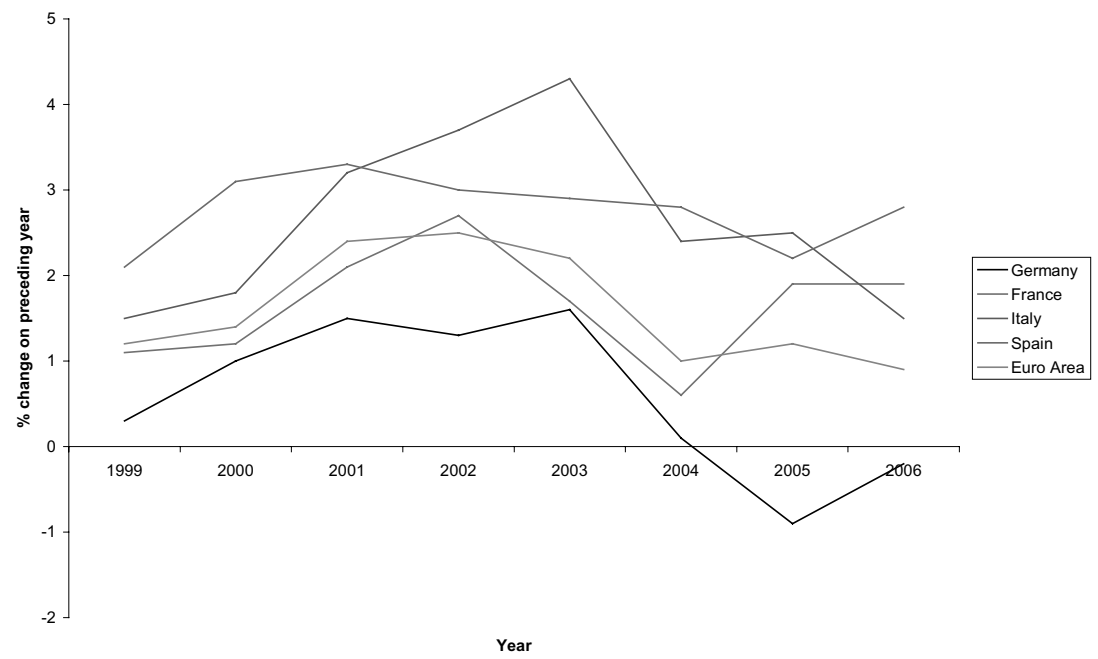

Source: European Commission Economic Forecasts Spring 2006

\section{Figure 6}

Relative unit labour costs, to rest of a group of industrialised countries (nat. curr.)

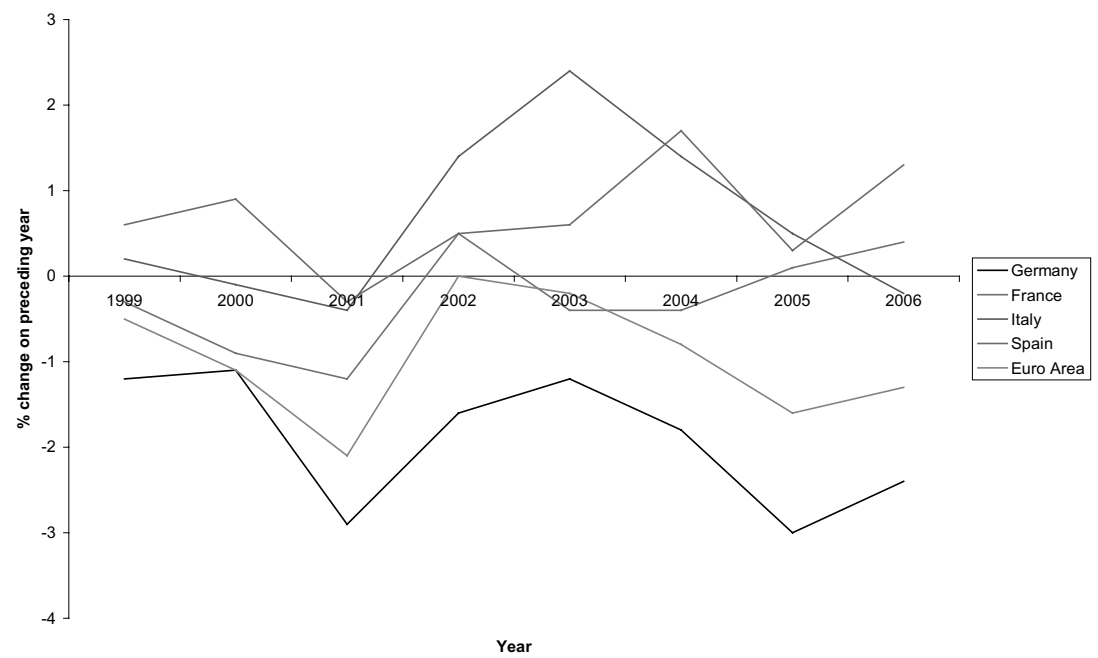

Source: European Commission Economic Forecasts Spring 2006 


\section{Figure 7}

\section{Current Account Balance}

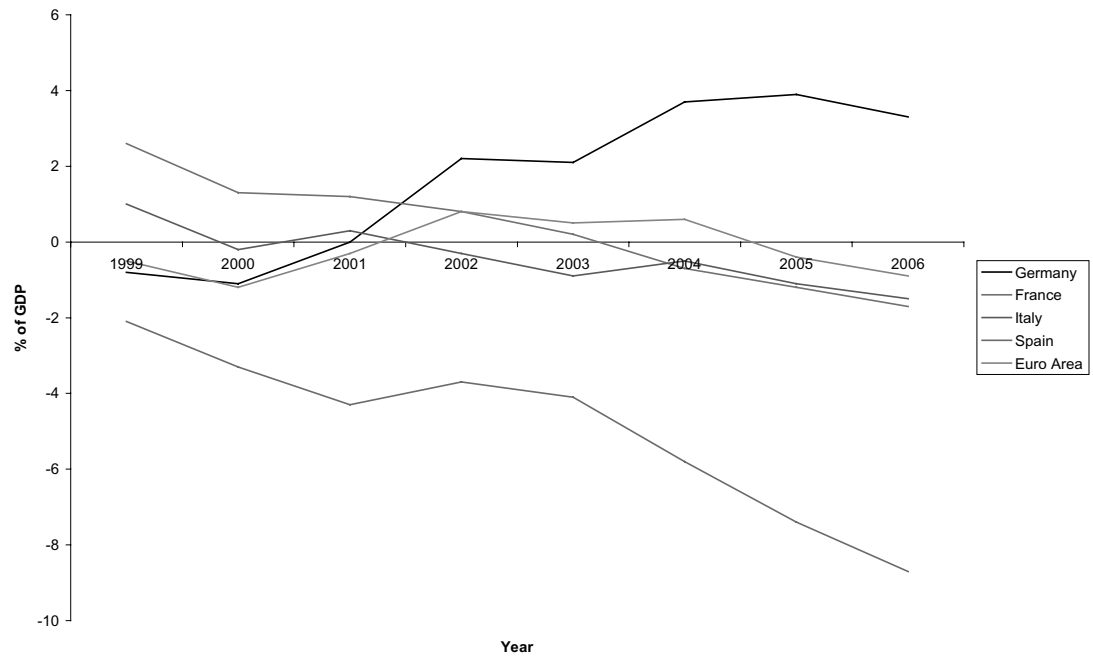

Source: European Commission Economic Forecasts Spring 2006

\section{Figure 8}

Current Account Balance

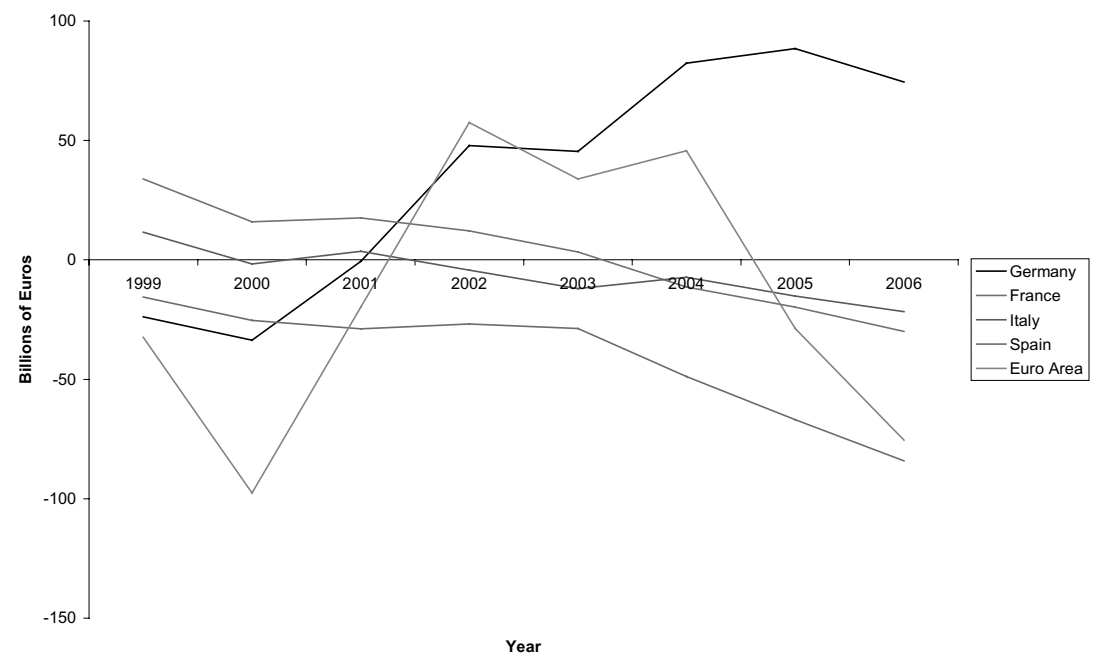

Source: European Commission Economic Forecasts Spring 2006 


\section{Figure 9}

Investment in construction, volume

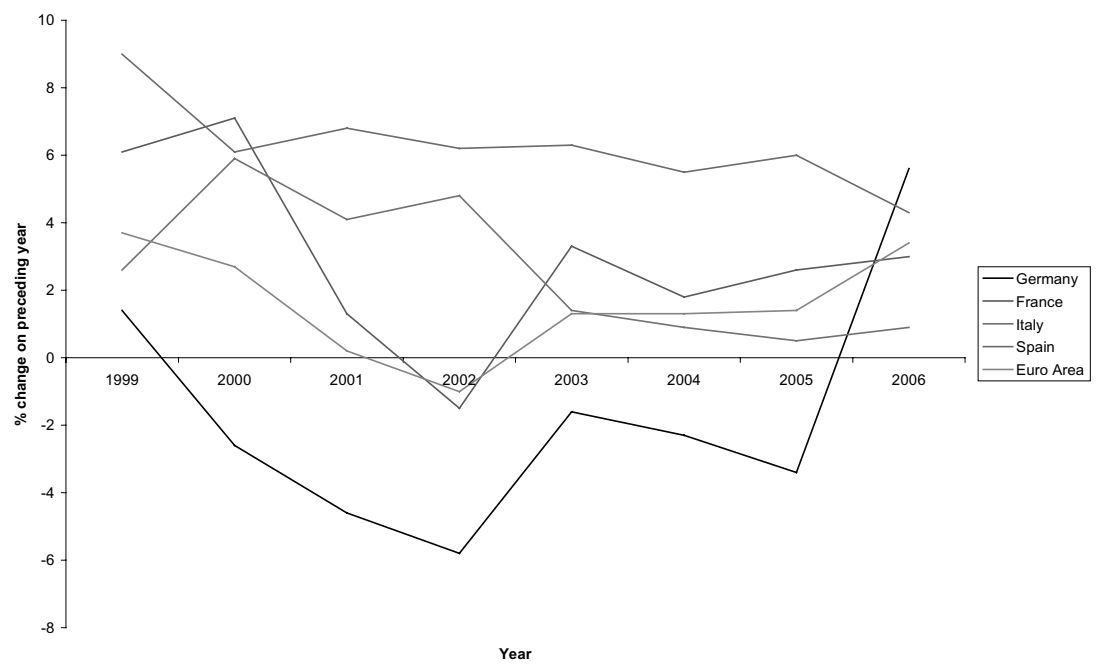

Source: European Commission Economic Forecasts Spring 2006

\section{Figure 10}

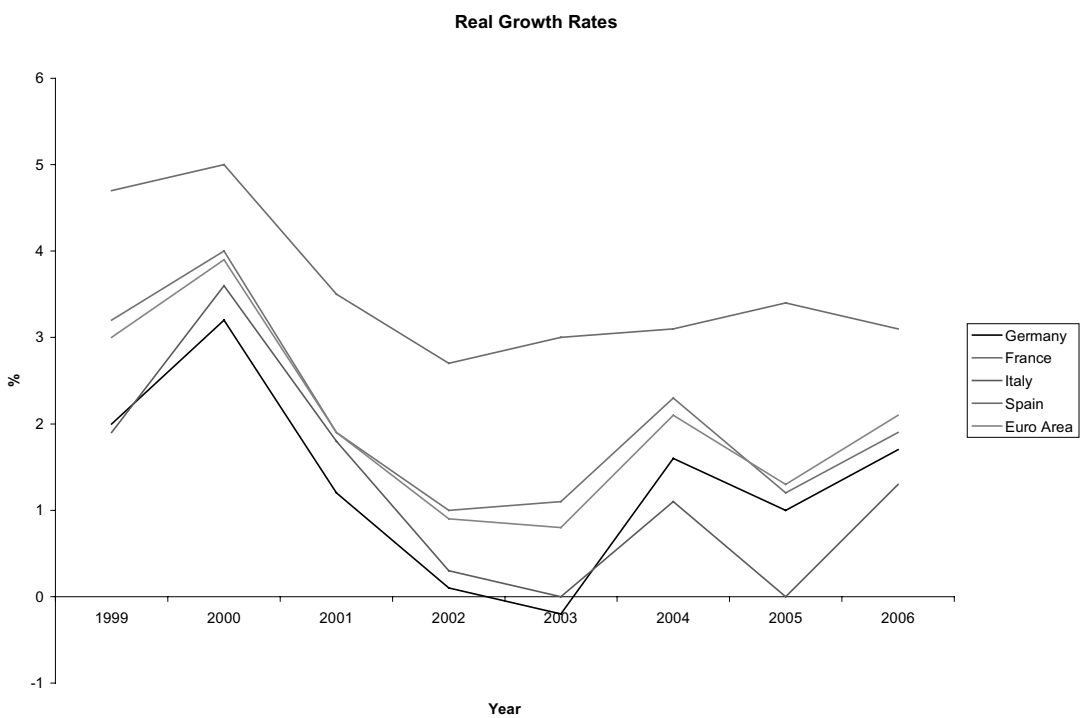

Source: European Commission Economic Forecasts Spring 2006 


\section{Figure 11}

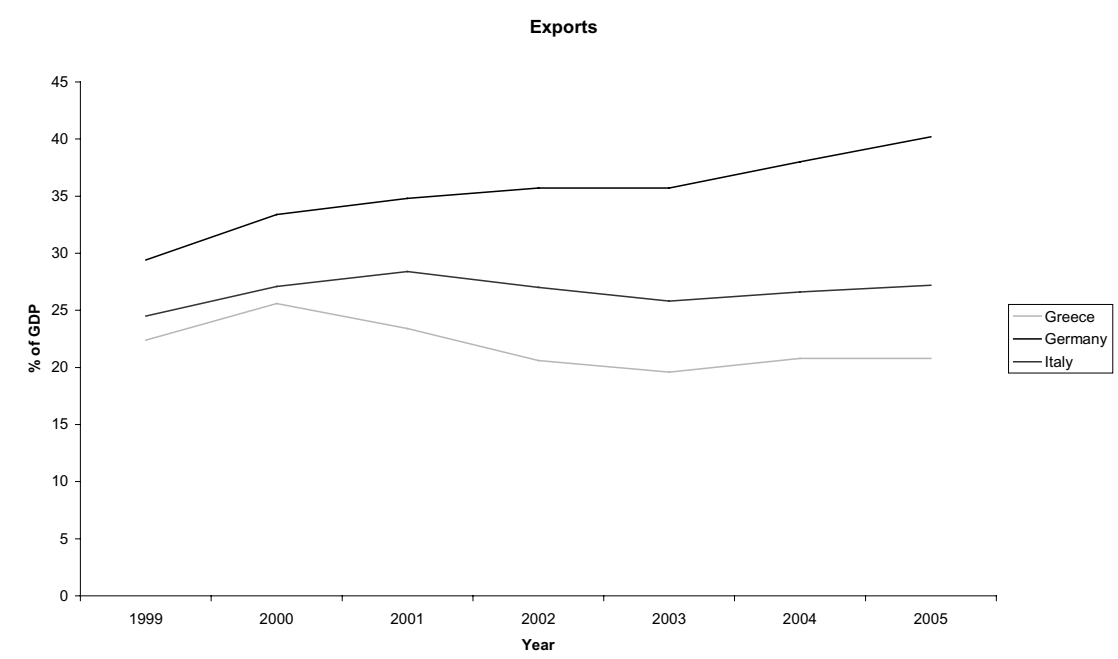

Source: International Financial Statistics May 2006

Figure 12

Unit Labour Costs, whole economy

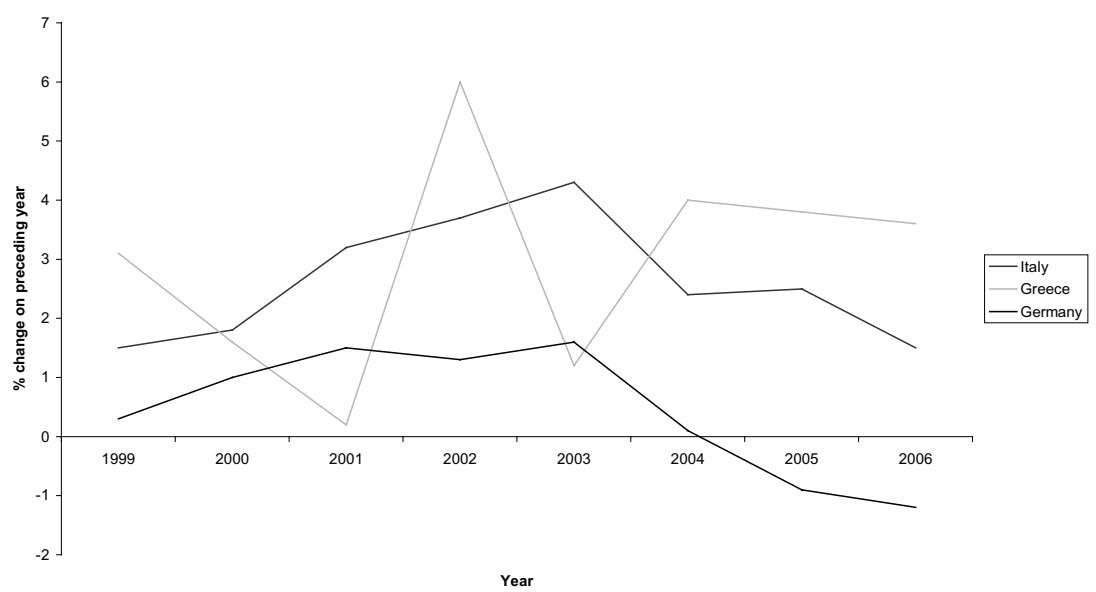

Source: International Financial Statistics May 2006 


\section{Figure 13}

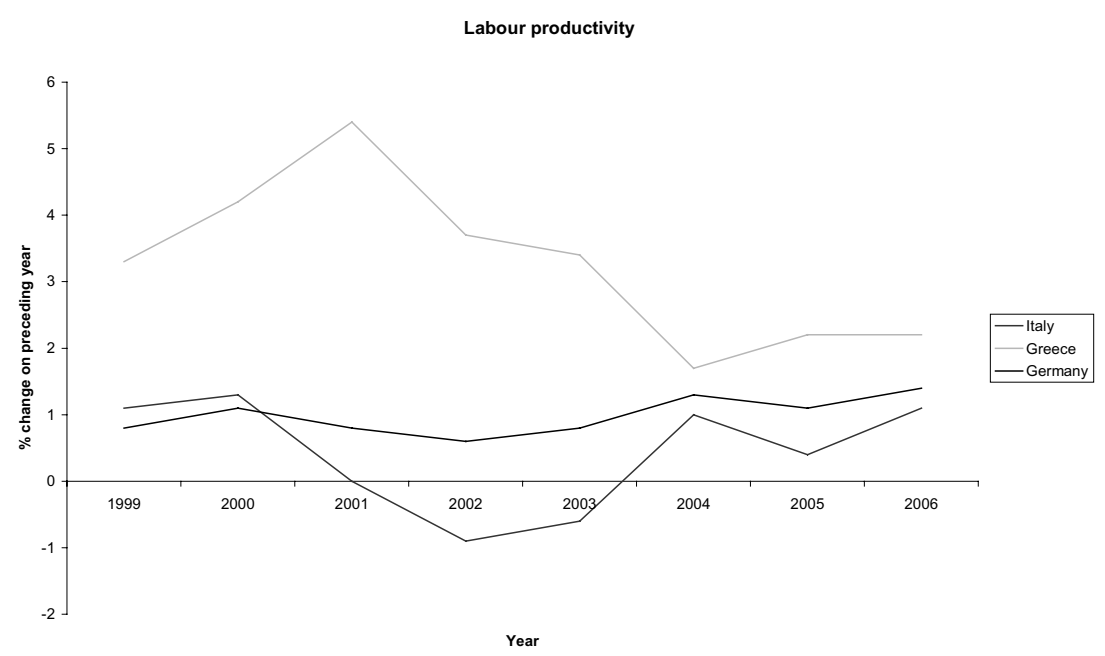

Source: International Financial Statistics May 2006

\section{Figure 14}

Nominal Wages

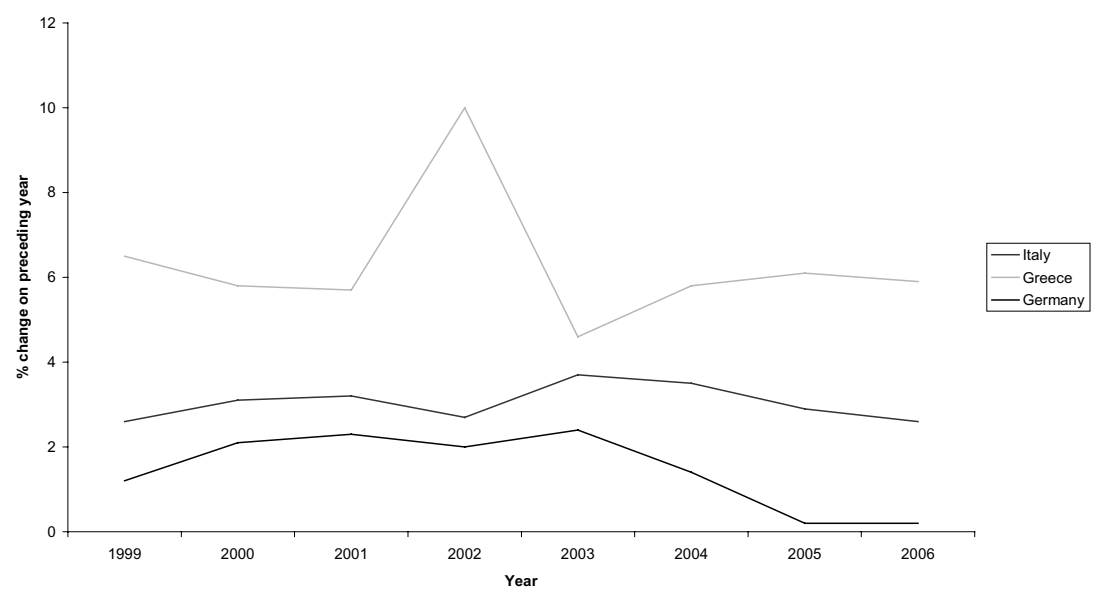

Source: International Financial Statistics May 2006 


\section{Figure 15}

Government bond yields, 10 years' maturity

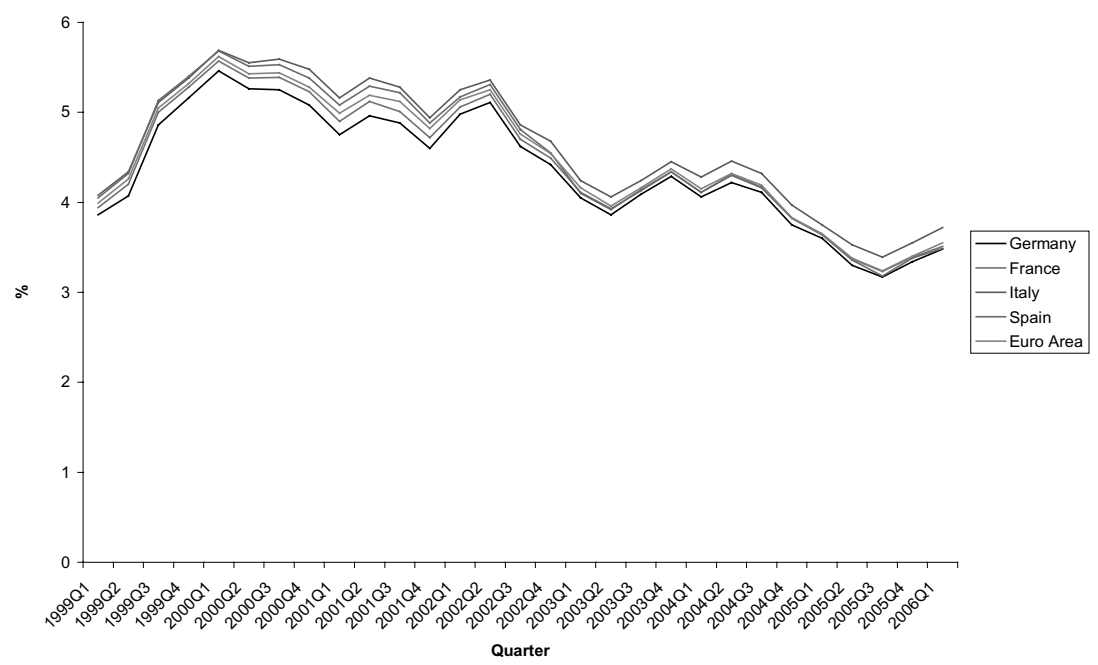

Source: Eurostat 
Table 1

\begin{tabular}{lrrrrrrr}
\hline & \multicolumn{7}{c}{$€ / \$$ Exchange Rates } \\
& 1999 & 2000 & 2001 & 2002 & 2003 & 2004 & 2005 \\
$\begin{array}{l}\text { Real Effective } \\
\text { Exchange Rate }\end{array}$ & 112.69 & 100 & 102.03 & 105.46 & 116.8 & 121.52 & 121.14 \\
$\begin{array}{l}\text { Nominal Effective } \\
\text { Exchange Rate }\end{array}$ & 111.46 & 100 & 101.19 & 104.28 & 116.07 & 119.98 & 120.27 \\
$€ / \$$ & 0.99542 & 1.07469 & 1.13469 & 0.95356 & 0.79177 & 0.73416 & 0.84767 \\
\hline
\end{tabular}

Table 2

\begin{tabular}{|c|c|c|c|c|c|}
\hline $2001-2004$ annual averages & 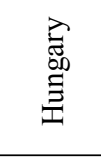 & $\begin{array}{l}\vec{E} \\
\frac{\vec{\sigma}}{0} \\
\text { 2 }\end{array}$ & $\begin{array}{l}\cdot \frac{\pi}{\pi} \\
\frac{0}{0} \\
\frac{0}{n}\end{array}$ & $\frac{\sqrt{n}}{\frac{\pi}{\frac{\pi}{\pi}}}$ & 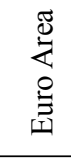 \\
\hline CA (bns of $€)$ & -5.400 & -5.975 & -0.075 & -1.225 & 29.3 \\
\hline Growth & 4.03 & 2.90 & 3.28 & 4.60 & 1.38 \\
\hline $\begin{array}{l}\text { Labour productivity (real GDP per occupied } \\
\text { person) (percentage change on preceding } \\
\text { year) }\end{array}$ & 3.85 & $\begin{array}{r}\text { No } \\
\text { data }\end{array}$ & 2.68 & 4.23 & 0.65 \\
\hline $\begin{array}{l}\text { ULC (whole economy, } \% \text { change on } \\
\text { preceding year) }\end{array}$ & 7.95 & $\begin{array}{r}\text { No } \\
\text { data }\end{array}$ & 6.05 & 3.70 & 2.03 \\
\hline $\begin{array}{l}\text { Relative ULC, to rest of a group of } \\
\text { industrialised countries }\end{array}$ & 5.75 & -1.80 & 3.8 & 1.58 & -0.78 \\
\hline $\begin{array}{l}\text { Net lending }(+) \text { or net borrowing }(-) \text {, general } \\
\text { government (as a percentage of GDP) }\end{array}$ & -5.93 & -3.88 & -3.03 & -5.23 & -2.53 \\
\hline
\end{tabular}

Source: EC Spring Forecasts 2006

Table 3

\begin{tabular}{rcccccc}
\hline 2004 & Greece & Italy & Portugal & Spain & France & Ireland \\
CA Balance (\% of GDP) & -9.5 & -0.5 & -7.8 & -5.8 & -0.7 & -0.8 \\
\hline Source: EC Spring Forecasts 2006 & & & & &
\end{tabular}




\section{Table 4}

\begin{tabular}{lcccccc}
\hline Spain & 2001 & 2002 & 2003 & 2004 & 2005 & 2006 \\
\hline $\begin{array}{l}\text { Compensation of employees per head } \\
\text { (percentage change on preceding year) }\end{array}$ & 3.6 & 3.3 & 3.4 & 3.3 & 2.5 & 3.3 \\
$\begin{array}{l}\text { Labour productivity (real GDP per } \\
\text { occupied person) (percentage change on } \\
\text { preceding year) }\end{array}$ & 0.3 & 0.3 & 0.4 & 0.5 & 0.3 & 0.4 \\
$\begin{array}{l}\text { Relative unit labour costs, to rest of a } \\
\text { group of industrialised countries (nat. curr.) } \\
\text { (percentage change on preceding year) }\end{array}$ & -0.3 & 0.5 & 0.6 & 1.7 & 0.3 & 1.3 \\
$\begin{array}{l}\text { Unit labour costs, whole economy } \\
\text { (percentage change on preceding year) }\end{array}$ & 3.3 & 3 & 2.9 & 2.8 & 2.2 & 2.8 \\
$\begin{array}{l}\text { Real Effective exchange rate: ulc relative } \\
\text { to rest of a group of industrialised } \\
\text { countries (usd) (\% change on preceding } \\
\text { year) }\end{array}$ & 1.1 & 1.9 & 5 & 2.9 & 0 & 1.3 \\
$\begin{array}{l}\text { Total investment, volume (percentage } \\
\text { change on preceding year) }\end{array}$ & 4.5 & 3.3 & 5.6 & 4.9 & 7.2 & 5.3 \\
$\begin{array}{l}\text { Investment in construction, volume } \\
\text { (percentage change on preceding year) }\end{array}$ & 6.8 & 6.2 & 6.3 & 5.5 & 6 & 4.3 \\
$\begin{array}{l}\text { Investment in equipment, volume } \\
\text { (percentage change on preceding year) }\end{array}$ & 0.1 & -2.9 & 2.5 & 3.7 & 9.5 & 7.9 \\
$\begin{array}{l}\text { Unemployment (as a percentage of civilian } \\
\text { labour force) }\end{array}$ & 10.3 & 11.1 & 11.1 & 10.6 & 9.2 & 8.7 \\
\hline
\end{tabular}

Source: EC Spring Forecasts 2006

Table 5

\begin{tabular}{|c|c|c|c|c|c|c|c|c|}
\hline $\begin{array}{l}\text { Net lending }(+) \text { or net } \\
\text { borrowing }(-) \text {, general } \\
\text { government (as a percentage } \\
\text { of GDP) }\end{array}$ & 1999 & 2000 & 2001 & 2002 & 2003 & 2004 & 2005 & 2006 \\
\hline Portugal & -2.8 & -2.8 & -4.3 & -2.9 & -2.9 & -3.2 & -6.0 & -5.0 \\
\hline Spain & -1.2 & -0.9 & -0.5 & -0.3 & 0.0 & -0.1 & 1.1 & 0.9 \\
\hline Italy & -1.7 & -0.6 & -3.1 & -2.9 & -3.4 & -3.4 & -4.1 & -4.1 \\
\hline Greece & -1.8 & -2.0 & -4.9 & -4.9 & -5.8 & -6.9 & -4.5 & -3.0 \\
\hline $\begin{array}{l}\text { Gross debt (as a percentage } \\
\text { of GDP) }\end{array}$ & 1999 & 2000 & 2001 & 2002 & 2003 & 2004 & 2005 & 2006 \\
\hline Portugal & 54.3 & 53.3 & 52.9 & 55.5 & 57.0 & 58.7 & 63.9 & 68.4 \\
\hline Spain & 63.1 & 61.2 & 55.6 & 52.5 & 48.9 & 46.4 & 43.2 & 40.0 \\
\hline Italy & 115.5 & 111.2 & 108.7 & 105.5 & 104.2 & 103.8 & 106.4 & 107.4 \\
\hline Greece & 105.2 & 106.2 & 113.2 & 110.7 & 107.8 & 108.5 & 107.5 & 105.0 \\
\hline
\end{tabular}

Source: IFS May 2006 
Table 6

\begin{tabular}{|c|c|c|c|c|c|c|c|c|}
\hline \multicolumn{9}{|c|}{ Exports (as \% of GDP) } \\
\hline & 1999 & 2000 & 2001 & 2002 & 2003 & 2004 & 2005 & \\
\hline Italy & 24.5 & 27.1 & 28.4 & 27 & 25.8 & 26.6 & 27.2 & \\
\hline Greece & 22.4 & 25.6 & 23.4 & 20.6 & 19.6 & 20.8 & 20.8 & \\
\hline Germany & 29.4 & 33.4 & 34.8 & 35.7 & 35.7 & 38 & 40.2 & \\
\hline \multicolumn{9}{|c|}{ Unit labour costs, whole economy (percentage change on preceding year) } \\
\hline & 1999 & 2000 & 2001 & 2002 & 2003 & 2004 & 2005 & 2006 \\
\hline Italy & 1.5 & 1.8 & 3.2 & 3.7 & 4.3 & 2.4 & 2.5 & 1.5 \\
\hline Greece & 3.1 & 1.6 & 0.2 & 6 & 1.2 & 4 & 3.8 & 3.6 \\
\hline Germany & 0.3 & 1 & 1.5 & 1.3 & 1.6 & 0.1 & -0.9 & -1.2 \\
\hline
\end{tabular}

$\overline{\text { Labour productivity (real GDP per occupied person) (percentage change on preceding }}$ year)

\begin{tabular}{lrrrrrrrr} 
& 1999 & 2000 & 2001 & 2002 & 2003 & 2004 & 2005 & 2006 \\
Italy & 1.1 & 1.3 & 0 & -0.9 & -0.6 & 1 & 0.4 & 1.1 \\
Greece & 3.3 & 4.2 & 5.4 & 3.7 & 3.4 & 1.7 & 2.2 & 2.2 \\
Germany & 0.8 & 1.1 & 0.8 & 0.6 & 0.8 & 1.3 & 1.1 & 1.4 \\
\hline
\end{tabular}

$\overline{\text { Nominal Wages: Compensation of employees per head (percentage change on preceding }}$ year)

\begin{tabular}{lrrrrrrrr} 
& 1999 & 2000 & 2001 & 2002 & 2003 & 2004 & 2005 & 2006 \\
Italy & 2.6 & 3.1 & 3.2 & 2.7 & 3.7 & 3.5 & 2.9 & 2.6 \\
Greece & 6.5 & 5.8 & 5.7 & 10 & 4.6 & 5.8 & 6.1 & 5.9 \\
Germany & 1.2 & 2.1 & 2.3 & 2 & 2.4 & 1.4 & 0.2 & 0.2 \\
\hline
\end{tabular}

